\title{
PHILOSOPHICAL UNDERPINNINGS \\ OF THE CONCEPT OF SOCIAL MALADJUSTMENT IN THE MODERN WORLD
}

\section{Orlenko I. M.}

\section{INTRODUCTION}

Social, political and economic shifts that are taking place nowadays often disturb relationships between an individual and the society, negatively affect peoples` adaptive processes and impact the mechanism of inclusion of new members into the social system. Social adjustment, or social adaptation, is just one of the number of facets of the bigger issue of adaptation, that lies at the intersection of different disciplines, and viewing the issue from this variety of standpoints is one of the most important and yielding for comprehensive studies of people. Theoretical, social and philosophical analysis of factors of personality that contribute to maladjustment, that is aimed to develop strategies of effective adaptation of Ukrainians to the modern society is therefore particularly relevant. Increase in efficiency of the process of adaptation is linked to the need to review and broaden the framework of the phenomenon of social maladjustment.

Social philosophy studies the facts and processes of human interaction related to their vital interests and also the ways the acquired and inherited experience gets reflected in the minds and behaviours of the society. According to E. Fromm, a constant need to solve existential conflicts and search for higher forms of unity with the nature, other people and the self underpin all human actions. He also underlined that a human being has a thinking mind, selfconsciousness and imagination, however the striving for harmony produces irreconcilable contradictions between life and death, between human capabilities and their limits, and also between individual and social life ${ }^{1}$. Satisfaction with the extent to which the

1 Философия. Основные социально-философские учения:учебное пособие / Г.П. Ковалева. URL: http://uchebnik-online.net/book/231-filosofiya-osnovnyesocialno-filosofskie-ucheniya-uchebnoe-posobie-kovaleva-gp.html 
spiritual and cultural needs are met, with the functioning of an individual within the social system all define the quality of live. Transformations that occur as a result of the change of the quality of live can be broken into two directions: positive changes (growth) and maladjustment.

Changes that are common to the present-day society caused depletion of the resources serving for adaptation. This decline is manifested both at the group and at the individual level. Due to the inertia of socialization, which is combined of different historical events and circumstances, sudden and constant changes cause maladjustment of an individual at the macro level. At the micro level social maladjustment can be viewed as a self-sustaining process and also as the outcome of adjustment process. All of the above reflects the multitude of forms and functions of the social maladjustment and allows to perform social and philosophical analysis of interconnections between internal and external factors of personality maladjustment in the Ukrainian society these days. At the present time Ukrainian society lives through the period of a social and economic crisis, the time when the integrity of political and geographical borders is violated. This inevitably causes increase of the number of people that find themselves in hard life circumstances and also has impact on the mechanism of inclusion of individuals into the social system. Changes triggered by the crisis in the wider society reflect the state of discord lived by its individual members. In the economic domain this is related to change of the form of ownership, to domination of the market system, development of manufacturing, which is shifting towards wider use of robots and automated processes. In the political area the changes are triggered by democratization and integration, which required revision of the forms of political activity that had existed before and drawing of the new ones that would match the new situation in the country and generally in the world politics. In the social sector the changes we observe are related to the process of deinstitutionalization, the pension, medical and education reforms, and also to the social services reform. Changes in the legislation in the three important sectors, which are the pension system, healthcare and social services, will undoubtedly trigger emergence of the new social model that will differ considerably from the one that existed before. The consequences have not yet been 
examined careful enough and, despite that the governmental institutions would be expected to do so, such analysis and the respective prognosis are still pending. The reason why such prognosis is important is because it is likely that in several years a big group of the Ukrainian citizens - hundreds of thousands people - will be left without basic social support and means of survival.

Social situation in the past decades is a combination of a variety of different "social realities". Several social and economic vectors are in place at the same time, providing different social groups with specific "activity fields", or "social niches" for their adaptation. There is little doubt that the population is at the same time trying to adjust to social realities that are made of contradictions, which drags part of the society into maladjustment and the respective forms of behaviour that reveal this.

As part of the social and philosophical analysis of this issue we consider social maladjustment as a full or partial incapability to adapt to the social conditions and the changes in the quality of life. Therefore, we can talk about hindering of the connection between a person and an environment, which is manifested in inability to fulfil positive social roles in particular social conditions and according to individual capacities. This approach makes possible to view the environment as a holistic social construct that was seen by H. Spencer as a social organism. Therefore, for him adaptation of individuals was seen as a constant movement of an individual person towards the balance with the environment (the society).

\section{Social Maladjustment in the Cross-Disciplinary Approach}

Social maladjustment is an interdisciplinary phenomenon that is studied in a variety of scientific fields. A comprehensive approach towards social maladjustment of individuals, that considers all aspects of the processes of adaptation that are studied by the disciplines that view it from a social standpoint underscores the value of crossdisciplinary studies. Maladjustment, depending on a specific aspect that is analysed, can be divided into demographic, social and cultural, political, psychological, religious, social, technological, ecological, economic, ethnic and legal. In the light of the foregoing, it can be asserted that the concept of maladjustment lies in the cross-section of different fields of study. 
The issue of maladjustment should be considered together with other concepts, namely such as adaptation (or adjustment), deviation, delinquency, anomy, stress and the others.

Thus, the scope of biology is a research focused on an evolutionary mechanism of adjustment of people to the external conditions that are reflected in the change of the systems and functions of the organism, and also behavioural changes ${ }^{2}$.

Medical science looks into maladjustment as a disturbance of adaptation, but also as on an adjustment of the organism to internallyand externally-induced changes: dynamic inconsistency between an individual and the environment that interferes with the physiological processes, behavioural changes, development of pathologies. A total misbalance between the individual and the environment is incompatible with life, and the extent of maladjustment is revealed through disturbances of functional systems of the organism. Maladjustment can also trigger suicidal behaviours if the basic values cannot be followed ${ }^{3}$.

Ethnography studies composition, emergence (ethnogenesis), resettlement, historical and cultural relationships of different ethnic groups, their culture and daily life. For this discipline adjustment and maladjustment are adaptation (or absence thereof) of the population to the environment (the landscape) that occurs through development of specific behaviours.

Demography studies changes of the demographical behaviours triggered by transformation in the social, cultural and economic environments, and also impact of the demographic factor on the changes in the modes of operation of the social, cultural and economic sub-systems of the society - which are essentially the processes of adjustment and maladjustment.

Economy, which studies economic behaviours of people in the process of manufacturing, and also management thereof at the microand macro-levels, while not using specifically the terms adjustment/maladjustment, sets its focus on mutual adjustment of the economic agents, the economic systems to each other, which causes changes in the patterns of economic behaviour. Maladjustment of companies is manifested through disorganization of the internal

2 Толковый словарь терминов. URL: http://psychiatry.academic.ru/836

Толковый словарь терминов. URL: http://psychiatry.academic.ru/836 
structure and external connections, unconscious attempts to follow stereotypical patterns of reactions that were shaped in the previous system, which causes a range of particular issues ${ }^{4}$.

Pedagogy studies social maladjustment as violation of moral and legal norms by children and teenagers, distortion of values, social attitudes and as a malfunctioning of internal regulation. Social maladjustment is a deeper form than the school one. It is characterized by anti-social behaviours (swearing, smoking, alcohol consumption, conflicting behaviours) and alienation from the family and school ${ }^{5}$.

Psychology focuses on the strategies of self-realization of children, teenagers or adults that threaten an individual or the society ${ }^{6}$. According to C. Rogers, maladjustment is a state of mismatch, of internal dissonance, with the main source of it being the potential conflict between "I"-affirmations and the experience of a person in the real world.

Deviantology views maladjustment as declined ability to accept and fulfil requirements of the environment as meaningful for an individual and also the ability to realize one's individuality in particular social conditions ${ }^{7}$.

Sociology puts maladjustment within the framework of a general adaptation syndrome of $H$. Selier that sees the conflict as a consequence of mismatch between the needs of an individual and the limits set by social environment. This state of conflict causes personal anxiety, which in turn triggers protective mechanisms that operate on the subconscious level ${ }^{8}$.

All the disciplines mentioned above view social maladjustment as a contradiction, as a negative tone, a clash and a focus on a negative sense of it. This static approach towards social maladjustment limits the perspectives for examining this phenomenon as a self-sufficient object of a scientific study that has its own particular phenomenological features.

4 Корель Л.В. Социология адаптаций: Вопросы теории, методологии и методики. - Новосибирск: Наука, 2005. - 424 с.

5 Коджаспирова Г.М., Коджаспиров А.Ю. Педагогический словарь. - М: Академия, 2003. - 176 с.

6 Толковый словарь терминов. URL: http://psychiatry.academic.ru/836

Толковый словарь терминов. URL: http://psychiatry.academic.ru/836

8 Толковый словарь терминов. URL: http://psychiatry.academic.ru/836 
Social philosophy has interest in a comprehensive research of the issues we mentioned before, since a complex approach is common to it. Consideration of social maladjustment stems not only from the present-day social and cultural situation, with high level of uncertainty and complexity common to it. It has to be underlined that this interest is relevant at all times and in relation to all forms of social relationships.

Philosophical analysis of the works dedicated to adjustment and maladjustment allows us to view the issue at the higher level, which is the framework "state - individual".

Thus, gender aspects of the cultural conflict that leads to social maladjustment is studied in the work of Tinghu Kang (2017). He underlines that a positive social support of the migrant workers can improve integration of their bi-cultural identity and contribute to better social adaptation ${ }^{9}$.

The model of social and psychological adaptation of migrants in the multicultural host community is defined in the work of V. V. Konstantynov (2018). According to him, non-linear dynamics and multidimensionality of the adaptive processes, depending on the intentions and the expectations of the social environment, helps social and psychological adaptation of migrants in the multicultural society. The researcher also suggested the typology of the adaptive processes: wish-based (cosmopolitan, temporary, permanent), behaviour-based, depending on the particularities of the situation of migration (active adaptation, passive maladjustment). He particularly underlines that the social and psychological adaptation of migrants is a long-term nonlinear systemic transformation of the relationships between a person and the environment. This will support the transition from preadaptation, combined with forming of the positive attitudes to a host country, to adaptation, that is characterized by the change of lifestyle, emergence of a dumper environment, selection of the strategies of behaviour and the mutual adjustment ${ }^{10}$.

9 TinghuKang (2017). Who Am I? Migrant Workers' Bicultural Identity Integration, Social Support, and Social Maladjustment. Social Behavior and Personality: an international journal. DOI: 10,2224 / сб.6645. URL: https://www.researchgate.net/publication/320247583

${ }^{10}$ Константинов В.В. Социально-психологическая адаптация мигрантов в принимающем поликультурном обществе. URL: https://www.sgu.ru/sites/default/ files/dissertation/2018/06/25/konstantinov_dissertaciya.pdf, p. 136. 
QianMeng, ChangZhu, ChunCao (2018) were researching the wider competency of foreign students through language mastery and social adjustment, and also the social cohesion in the international community. The researchers were viewing the competency of the students as an intermediary between the mastery of a foreign language (English and another European language, none of which was native for them). Analysing the results of this research we can conclude that the wider competency was partially responsible for the link between knowledge of English and the social cohesion, however it had a strong and deep influence on the link between mastery of the foreign language and the social adjustment ${ }^{11}$.

Studying mutual social and cultural adaptation, E. R. Boryshtein underscored the centrality of the questions of sustainability, tolerance towards other people and the values to the ability to live in a new social environment. According to him, the most important factors here are not only economic realities and the morale, but also the social and cultural environment, the cultural universalisms ${ }^{12}$.

For studies into social adaptation/maladjustment of families with kids with special needs the important criterions are the "social quality" and the "quality of life". Birth and upbringing of a child who has special needs decreases the quality of life of the family, its social quality and triggers negative reactions and anxiety that cause stress in parents. This in turn leads to social maladjustment.

LL McIntyre, M Brown (2018) studied social support that was described as a vital resource for the families who have kids with special needs. Research data shows that parents of the children who have autism spectrum disorder (ASD) experience increased pressure and stress compared to parents with children who have other intellectual or developmental pathologies.

As stated by H. Sokolova who researched development of the social and psychological mechanisms and the social relationships of children with Down syndrome in the micro- and macro- environment,

11 Qian Meng, Chang Zhu, Chun Cao (2018) Chinese international students' social connectedness, social and academic adaptation: the mediating role of global competence. Higher Education: International Journal of Higher Education Research. T 75, В 1, c. 131-147 https://doi.org/10.1007/s10734-017-0129-х

12 Боринштейн Е. Р. Взаимная социальная адаптация как фактор коэволюции общества / Е. Р. Боринштейн // Соціальнітехнології = Социальные технологии. - 2003. - Вип.20. - С. 20-25. 
social adjustment is defined as the particularities of sensory perception and development of mental patterns. Its function, according to the author, is in development of the ability to find a way in the environment and is realized through functional literacy ${ }^{13}$.

Philosophical analysis of the issue of adjustment/maladjustment in parents of kids with physical and psychological developmental problems through a review of recent academic papers and dissertations from different scientific fields allows us to conclude that birth and upbringing of such a child causes a range of negative reactions and experiences in parents. The emotional states common to this situation can be seen as crisis conditions, combining emotional distress, depressive tendencies, situation-related and personal anxiety that are all signs of social maladjustment. Existential crisis, cognitive disorientation of parents, hidden self-destruction of parents and selfidentification crisis, loss of life prospects, loss of balance in the family relationships, "escape" of parents into work or self-denial, that occur as a result of setting a child as a priority, and social isolation are the consequences of those states. It has been found that inclusive nature of the psycho-emotional states plays an important role for defining direction, intensity and the coherence of steps aimed to give support to a child; also for the parental position and the ability to live to their full potential in the family and wider society.

Having analysed the research presented above, we can conclude that social maladjustment as well as social adjustment are some of the most important processes for all areas of life of an individual that have a considerable impact on them. According to our study, the phenomenon of social maladjustment depends on specific factors: the hierarchy of the existing and potential social, psychological and physical needs of a person and society; issues and the adaptive reactions; mental models (contributing to maladjustment ) that are shaped as a person grows up and interprets the social roles and the life purpose and also on the presence or a complete absence of individual adaptive capabilities (relationships with other people, personal needs and self-consciousness). This link allows us to talk about the stages of emergence of maladjustment. Under the emergence of maladjustment we view interdependencies and connections between different levels

13 Соколова Г.Б. Психологічні особливості захисної поведінки батьків, що виховують дітей із синдромом Дауна. Наука і освіта. 2017. № 3. С. 23-28. 
of this process, which will allow to create a more precise structure of social maladjustment in the future. An individual (but also an organization, institute, society and any social system) that goes towards maladjustment passes the following stages: 1) initial - vital processes are disrupted; 2) search of adaptive resources; 3 ) response to changes of the environment: a) partial adjustment, b) sustainable nonadjustment. Maladjustment in every specific case depends on biological and social stimuli, past experiences of adjustment/maladjustment, social position of maladjusted person (power, resources under control, social connections etc.).

Adjustment and maladjustment have similarities related to their structures and consist of the core that brings together all individual, personal, behavioural, informational and adaptive resources accumulated by an individual at a particular time that are utilized in the crisis situation.

Social maladjustment is viewed as a total or partial loss of ability to adapt to the conditions set by society and to the changes in the quality of life. It is a disruption of the link between a person and an environment when an individual is unable to fulfil a positive social role in particular social conditions and to his full potential ${ }^{14}$.

In our opinion, the main components of social maladjustment are directly linked to the structure of personality and his relationships with the society according to the personal qualities. For this reason, in order to get a more precise idea about the components of social maladjustment we take the structure of personality as a foundation to build upon. Philosophy views the personality through the lens of universality in the system "universe - individual", whereas other disciplines take a narrow approach towards personality, based on the specific subject of their study. Personality defines an individual, namely, as an actor in the social and public relations, it is an extent of unlikelihood, a manifestation of the features that are common only to this individual that differ him from the others. Personality is not simply something that is common to a particular individual, it can be seen as a summary of relationships that exist in the society ${ }^{15}$.

14 Солодовников В. Социология социально-дезадаптированной семьи / В. Солодовников - СПб.: Питер, 2007. - 384 с., p. 76.

15 Философская концепция личности. URL: https://uchebniki-besplatno.com/ obschaya-filosofiya/filosofskaya-kontseptsiya-lichnosti-53699.html 
The issues related to the concept of personality cannot be solved without questioning the links between the society and an individual. In our opinion, it is not possible to understand the essence of personality without understanding the concept of it. An individual is a social unit, a source of the system of social relationships (according to the 10 areas of the social life, as the system-generating institutions that are rooted into the basic forms of social activity), with his own psyche, personal culture, consciousness and actions. Public relationships that form the environment in which an individual grows and develops is dialectic, therefore, the feedback system determined by the actual situation plays a role ${ }^{16}$.

Multi-layered structure of social maladjustment and the way it inevitably influences the social structure, and also the degree of its impact on individual people and their environment attract attention of different scholars, namely, the ones working in social sciences, social ecology, philosophy, cultural studies, biology, medical science, social linguistics, economics, political studies and demographic studies. Universality of adaptation as a social process that supports and reflects life patterns of an individual in all ways they are manifested suggests the need to view adjustment and maladjustment in a multidisciplinary context.

\section{Philosophical Approach Towards the Phenomenon of Social Maladjustment}

The majority of conceptions of maladjustment are linked to research in the social sciences domain, which aim to identify its causes in the social structures and cultural factors: the conception of the influence of the society and culture on the development of personality (E. Fromm, E. Ericsson, K. Horney, G. Sallivan, J. Bowlby, A. Adler, V. M. Miniyarov), the conception that behavioural disorders in children are caused by a loss of connection with their emotions in the given environment in which a child is brought up (A. Maslow, A. Bandura), the conception that environment influences the behaviour of a person (B. Skinner, E. Torndike, D. Watson), the idea of common impact of the individually impactful

16 Человек как личность. URL: https://studme.org/1053052417779/filosofiya/ chelovek_kak_lichnost 
and the socially common features and qualities (L. I. Bozhzych, B. S. Bratus, B. V. Zeigannyk, A. N. Leontiev. V. S. Mukhina, V. F. Pirozhkov, L. S. Slavina et al.), the conception of a deviant behaviour (Y. A. Kleiberg), the deficit-based conception of personality disorders (E. V. Rudensky), the conception that the external factors influence the behaviour of a child while changing based on the inner states (S. A. Belycheva, M. I. Buyanov, V. V. Kovalev, M. Y. Kondratiev, G. V. Akopov, V. P. Zinchenko et al.).

One of the most important components of social maladjustment is the discord between the ambitions and self-esteem of a person and his capabilities and the social reality. Social maladjustment disrupts the interconnection between the processes of interiorization and exteriorization of biological and psycho-social capabilities of a person.

Looking into the notion of social maladjustment, we consider the normative meaning of the phenomenon of social maladjustment, which allows to balance the influences that cause maladjustment in the system "personality - society". The essence of adaptation can be presented as a confrontation of two opposite powers: the one who is trying to adjust and the object of adjustment. These two components are needed both for adaptation and for maladjustment, since the confrontation is strong in the pairs of notions "subject-object of adjustment / maladjustment", which are considered by philosophy, or the "external environment-system" which is borrowed from cybernetics.

The issues of social adjustment and social maladjustment have a strong connection and are complementary. Development of systemic approach allows us to say that adjustment is a functional sign of complex self-managing systems.

Modern theoretical definition of social adjustment stipulates that it is a process and a result of creation of balanced relationships between an individual and a social macro-environment in the social situations particular for this individual. The scope of the processes of adaptation and their place in the social life have been studied by the followers of the "classical" social science, namely, by E. Durkhaim, M. Weber, T. Parsons et al. 
E. Durkhaim did not use the term adjustment. He studied adaptation of inner structure of an individual to existing social norms. M. Weber, while acknowledging the role of social norms, also underscored the importance of the issue of whether the social norms match the interests and expectations of an individual. An individual searches for the norms that better suit him in the patchwork of social values, and also changes and creates the norms by himself. M. Weber views those as purposeful-rational and also as value-oriented-rational actions and stipulates that this way of adjustment of an individual to the society is source of social progress ${ }^{17}$.

Modern scholars who focus on the interconnection between a personality and the process of being from the point of search for the resources for adaptation view the issue of adjustment from different dimensions. Thus, a philosopher E. V. Illienkov noted that individual differences between people and psychological processes are determined only by the social factors, and the conception that the psyche is socially determined is the only yielding approach. He suggested that all specific human functions of the brain and all structures that ensure them emerged as a result of people living as social animals ${ }^{18}$.

Of particular note are the works of A. I. Kavalerov, A. M. Bondarenko, E. R. Borynshein, dedicated to social adjustment in relation to the life of modern society.

The phenomenon of social adjustment and its manifestations in the current realities was studied by A. I. Kavalerov, A. N. Bondarenko. They suggested that "incompleteness of transition period in the post-Soviet Ukrainian society, lack of clear developmental pathways, inconsistency in actions in the political and governmental structures as well as other negative factors cause frustration in a significant part of the population. One of the forms of its manifestation is depression, and the other way is through negative emotions, tension, emotional distress, discomfort, pessimism, which makes the social adjustment process lacking in prospects and having

17 Солодовников В. Социология социально-дезадаптированной семьи / В. Солодовников - СПб.: Питер, 2007. - 384 с.

18 Кансиярова Е.А. Социальная адаптация молодежи (автореферат) URL: http://cheloveknauka.com/sotsialnaya-adaptatsiya-molodezhi 
little efficiency..."19 and in our opinion leads to sustainable maladjustment.

Studies aimed at identification of the level of individual satisfaction with the position within the society have gained particular attention from scholars and, according to A. I. Kavalerov and A. M. Bondarenko, the aforementioned satisfaction is the ability of a person to assert their creative potential in sensual and emotional ways, and realize it. Each individual belongs to many social groups, however the level of adaptation to each one of them can be different: whereas in one group an individual can be highly adaptive, the same person can be maladjusted in the other. Scientists note that "adjustment as a consequence of adaptive processes plays a role in stabilizing the social organism, ensuring its integrity and progress",20.

As stipulated by E. R. Borynshtein, "traditional approach towards social adjustment as to adaptation of social subjects to conditions, norms and values of the new social environment in the modern conditions requires a deeper look and consideration of the process of adaptation as an outcome of a reciprocal process that includes activity of a subject, object and the social environment, which is defined as mutual social adjustment in the modern science" 21 . In his research he points at the contradictions related to social and cultural adaptation of the Ukrainian society and notes that the "dynamics in the processes of mutual adjustment is most significantly defined by the change of the type of relationships between the elements of the cultural system that ensures adjustment of the new social system that is formed in the transition period towards the dominating world system" 22 .

Traditionally maladjustment was explained through disruption of the process of social adjustment and related to inconsistency between a behaviour and the requirements of the society. In the changed life

19 Кавалеров А.І. Соціальна адаптація: феномен і прояви: Монография. Одесса Астропринт, 2005. - 112 с., р. 88.

20 Кавалеров А.І. Соціальна адаптація: феномен і прояви: Монография.Одесса Астропринт, 2005. - 112 с., р. 102.

21 Боринштейн E.P. Особенности социокультурной трансформации современного украинского общества: Монография. - Одесса Астропринт, 2004. 400 c., P. 178.

22 Боринштейн Е.Р. Особенности социокультурной трансформации современного украинского общества: Монография. - Одесса Астропринт, 2004. 400 c., c. 178. 
conditions defining maladjustment includes considering individual particularities, external support and revelation of inner resources.

At the social level maladjustment can be viewed as a breakdown of interaction between a person and the social environment as a whole. Maladjustment, as well as adjustment, is defined by the three levels: the course of its development, specific manifestations and the result.

Maladjustment as a process means decrease of the adaptive capacities of an individual in his living environment or in relation to particular social institutions in which he operates.

Maladjustment as a social issue is a manifestation of a functional incapacity of an individual that is reflected in uncommon behaviours, relationships and the outcomes of his activity in the given conditions.

Maladjustment as an outcome points also at the comparison of the new condition and its manifestations (that do not match the external conditions and are not common to this person) and the past behaviour and relationships of this individual.

The variety of definitions of maladjustment also suggests that it can be quite ambiguous, which is suggested by defining the place of maladjustment in relation to the categories of normal and pathological reactions and behaviours. It should also be taken into consideration that the authors can view it as a process, as a manifestation and asa result.

When maladjustment is viewed as a process, it means that the adaptive capacities of a person in the environment or certain conditions are reduced (at the kindergarten, class, a group etc.). In this case maladjustment can be revealed over a significant amount of time and lead to different outcomes.

Particular patterns can be:

- it can have low intensity and be nearly discreet, at the same time becoming a serious issue for an individual;

- be clearly manifested, a person appears completely not able to adjust to a particular situation and find his way out. The consequences in this case can be quite serious. Continuous maladjustment in children can cause stunting, emergence of negative attitudes, cause anxiety etc.

Maladjustment is an external manifestation of individual malfunctioning which is reflected in uncommon behaviours and the outcomes of his activity at a given environment. The forms of its manifestation are very individual, and it is often hard to identify its presence by outward signs. 
We suggest that the number of individuals experiencing social maladjustment in the present-day Ukrainian society is big. As the quality of life changes, a range of social needs of people remain unfulfilled, namely, in the families with children with physical and psychological developmental issues, single-parent families, families with hard living conditions, low-income families and the displaced families from the zone of the military conflict in the Eastern Ukraine (ATO zone).

Quality of life in the broad sense can be identified as the perception by an individual of his own life. Hence, the quality of life is a subjective notion. It includes both existential aspects, the way a person feels about himself, and also his assessment of his own actions as opposed to social functioning which can be assessed externally. In this regard, as we suggest, the term "quality of life" can be viewed as a synonym to the notions of social adjustment and maladjustment and points at its internal and external factors. External factors are related to different aspects of life. Those are, namely, the conditions of living, social functioning, relationships, support of relatives, support from social workers and healthcare system, possibility to buy medicines, security, access to information. As to the internal factors, those are individual features of a person.

Based on the aforementioned points, we can conclude that among the factors of social maladjustment are: relative cultural and social deprivation (non-fulfilment of vital needs), social immaturity, psychological and pedagogical neglect, aggressive deviations, loss of the mentorship connections that have already been created, loss of social connections, disruption of dynamic stereotypes, accentuation of character, development of psychopathic features in person, social inertia, unpreparedness to self-regulation processes, cognitive dissonance as a result of mismatch between assumptions related to life and the real situation.

Recent academic research suggests five most important reasons that cause social maladjustment: social, biological, psychological, agerelated, and social and economic ${ }^{23}$.

${ }^{23}$ Социальная дезадаптация. URL: http://psihomed.com/sotsialnaya-dezadap tatsiya/ 
Based on the causes and factors, the following types of social maladjustment can be defined: related to social environment and life conditions, legal, situation- and role-related, sociocultural.

Maladjustment related to social environment and life conditions means that an individual experiences dissatisfaction with his life conditions. Maladjustment related to the legal aspect means that a person disagrees with his place in the society and social hierarchy. Situation- and role-related type can be described as a short-term maladjustment that is related to a perceived wrong social role in a particular situation. Social and cultural occur when a person is unable to accept the mentality and culture of the society in which he lives ${ }^{24}$.

Analysis of the philosophical dimension of social maladjustment allows us to consider it as a combination of properties that create a system that does not allow an individual to make up his own life that has a sense and value. As a result of social deprivation a person loses opportunities to personal development and finds himself in the conditions of social and cultural isolation, loses a sense of belonging to a common culture and starts appropriating the values and attitudes of micro-environment. Therefore, his only aim becomes an escape from negative emotions caused by a traumatizing situation.

\section{CONCLUSIONS}

Living in a modern world is related to a number of stresses: global calamities, shocks and wars are very common. Depletion of natural resources increases the likelihood and frequency of military clashes. Changes come fast, and the number of events occurring at exact same moment grows: Chernobyl, plane crashes and railway accidents.

Social shifts pose a great challenge to adaptive potential of present-day society. As the society passes through evolutionary and revolutionary developmental processes, adjustment that occur within it becomes a mechanism that serves for coordination and mutual alignment between the elements of the public system. At the same time these processes become more intense, which is particularly explicit as the modern social world moves towards bigger extent of globalization and modernization. Adaptive barriers have a significant impact on the outcome of the process of adjustment. The nature of

${ }^{24}$ Социальная дезадаптация: причины, факторы, виды.. URL: http://allbest.ru/sociology/00184939 
those barriers can be, namely: emotional and psychological; pedagogical; age-related; professional; intellectual; attitudinal; informational; national and cultural; regime-related. Maladjustment in all these cases is manifested in different ways. Moral and legal normative personality maladjustment can be conformist, innovative and ritualized, while maladjustment as impossibility for an individual to find his way in the social domain comes up as a rejection of the existing social and cultural norms.

Traditionally maladjustment was interpreted as disruption of the process of social adjustment and related to mismatch between behaviours and requirements of the society. Inconsistency between claims of the person, his self-esteem and the possibilities of the environment is one of the key component of social maladjustment. In each specific case maladjustment depends on biological and social stimuli, on the experiences of past adjustment and maladjustment, social position of a maladjusted person (power, resources under control, social networks etc.). Social maladjustment disrupts the interconnection between the processes of interiorization and exteriorization of biological and psycho-social capabilities of a person. It must be noted that changes that occurred in the social, economic and political fields in Ukraine caused depletion of the resources that support the processes of adjustment in the most vulnerable groups of population. This allows us to view social maladjustment from different dimensions and define all define the notions that are

Social shifts pose a great challenge to adaptive potential of present-day society. Many people find themselves in the changed and uncommon environment, which causes social maladjustment in the long term. This maladjustment can be temporary and permanent, internal and external. Therefore consideration of social maladjustment in a wider framework as well as defining various components that make it up as an object of philosophical research can contribute to creating a new social and communication model in the public relationships.

\section{SUMMARY}

The article focuses on different causes of social maladjustment of individuals in the present-day Ukrainian society. It points at the 
growing interest to the aspect of personality maladjustment that are linked to complexity and vagueness of social and cultural context, to modernization of the state and the society. It has been determined that social maladjustment is a multidisciplinary phenomenon, and the majority of conceptions related to it stem from the efforts to find its causes in the social structures and cultural factors. Social philosophy allows to investigate the level of satisfaction with the extent to which spiritual and cultural needs of a person are met, as well as satisfaction with life in general and with the conditions in the society. It is for that reason that it is important to elaborate and broaden the definition of individual social maladjustment, in accordance to the reality and the facts. Philosophical comprehension of social maladjustment is particularly relevant given the changes common to the modern life.

\section{REFERENCES}

1. Философия. Основные социально-философские учения: учебное пособие / Г. П. Ковалев. URL: http://uchebnik-online.net/ book/231-filosofiya-osnovnye-socialno-filosofskie-ucheniya-uchebno e-posobie-kovaleva-gp.html
2. Толковый
словарь
терминов.
URL:
http:// psychiatry.academic.ru/836

3. Гумилев Л. Этногенез и биосфера земли. URL: https://libking.ru/books/sci-/sci-history/287761-lev-gumilev-etnogene z-i-biosfera-zemli.html

4. Корель Л. В. Социология адаптаций: Вопросы теории, методологии и методики. Новосибирск: Наука, 2005. - 424 с.

5. Коджаспирова Г. М., Коджаспиров А. Ю. Педагогический словарь. - М: Академия, 2003. - 176 с.

6. Tinghu Kang (2017). Who Am I? Migrant Workers' Bicultural Identity Integration, Social Support, and Social Maladjustment. Social Behavior and Personality: an international journal. DOI: 10,2224 / сб.6645. URL: https://www.researchgate.net/publication/320247583_

7. Константинов В. В. Социально-психологическая адаптация мигрантов в принимающем поликультурном обществе. URL: https://www.sgu.ru/sites/default/files/dissertation/2018/06/25/konstantin ov_dissertaciya.pdf

8. Qian Meng, Chang Zhu, Chun Cao (2018) Chinese international students' social connectedness, social and academic 
adaptation: the mediating role of global competence. Higher Education: International Journal of Higher Education Research. T. 75, B. 1, c. 131-147. https://doi.org/10.1007/s10734-017-0129-X

9. Боринштейн Е. Р. Взаимная социальная адаптация как фактор коэволюции общества // Социальные технологии. - 2003. Вип.20. - С. 20-25.

10.Соколова Г. Б. Психологічні особливості захисної поведінки батьків, що виховують дітей із синдромом Дауна. Наука і освіта. 2017. № 3. С. 23-28.

11.Солодовников В. Социология социальнодезадаптированной семьи. - СПб.: Питер, 2007. - 384 с.

12.Философская концепция личности. URL: https:// uchebniki-besplatno.com/obschaya-filosofiya/filosofskaya-kontseptsiyalichnosti-53699.html

13. Человек как личность. URL: https://studme.org/1053052 417779/filosofiya/chelovek_kak_lichnost

14.Кансиярова Е. А. Социальная адаптация молодежи (автореферат) URL: http://cheloveknauka.com/sotsialnaya-adapta tsiya-molodezhi

15.Кавалеров А. І. Соціальна адаптація: феномен і прояви: Монография.-Одесса Астропринт, 2005. - 112 с.

16.Боринштейн Е. Р. Особенности социокультурной трансформации современного украинского общества: Монография. - Одесса Астропринт, 2004. - 400 с.

17. Социальная дезадаптация. URL: http://psihomed.com/ sotsialnaya-dezadaptatsiya/

18. Социальная дезадаптация: причины, факторы, виды. URL: http://.allbest.ru/sociology/00184939

\section{Information about the author: Orlenko I. M.,}

Ph.D., Department of Philosophy, Social Sciences and Management of Social and Cultural Activities,

State institution "South-Ukrainian

National Pedagogical University named after K. D. Ushynsky" 26, Staroportofrankivska str., Odesa, 65020, Ukraine 